\title{
Ovine Eimeria infections in southern Brazil - prevalence and risk factors
}

\section{Infecções por Eimeria em ovinos do sul do Brasil - prevalência e fatores de risco}

\author{
Natália Soares Martins ${ }^{1 *}$; Sara Patron da Motta ${ }^{1}$; Carolina Caetano dos Santos ${ }^{1}$; \\ Andrios da Silva Moreira ${ }^{1 ;}$ Tainá Ança Evaristo ${ }^{2 ;}$ Nara Amélia da Rosa Farias ${ }^{3 ;}$ \\ Jerônimo Lopes Ruas ${ }^{4}$
}

\section{Highlights}

High prevalence in animals and herds.

Pathogenic Eimeria species were the most prevalent.

Age and management practices were risk factors associated with protozoan infection.

\begin{abstract}
Eimeria infections are common in sheep industry worldwide, however information about their epidemiology is scarce in southern state of Rio Grande do Sul, Brazil. Therefore, a cross-sectional study was carried out to determine the prevalence, species characterization, and associated risk factors between Eimeria species and sheep flocks. Fecal samples from 428 sheep from 21 farms were tested for the presence of oocysts. The overall prevalence of Eimeria spp. was $68.69 \%$ and was significantly affected by age of the sheep, with highest prevalence in animals under 18 months of age. Eight Eimeria species were identified. Eimeria ovinoidalis (85.71\%) was the most common, followed by Eimeria crandallis (80.95\%), Eimeria granulosa (78.95\%), Eimeria ahsata (61.90\%), Eimeria faurei (42.86\%), Eimeria bakuensis (38.10\%), Eimeria punctata (14.29\%), and Eimeria pallida (9.52\%). All herds were positive, with concomitant infections. Among management and husbandry practices; farm size, animal density, farming system, breeding objectives, and pasture system influenced the prevalence of Eimeria species. The infection was more prevalent on small farms with high animal density, in sheep raised for meat, semi-intensive system, and rotational grazing $(p<0.05)$. The wide distribution of this protozoan and the high frequency of pathogenic species show the importance and potential damage of coccidiosis in sheep flocks in Rio Grande do Sul.
\end{abstract}

Key words: Coccidiosis. Eimeria crandallis. Eimeria ovinoidalis. Sheep.

1 Drs. Students, Graduate Program in Microbiology and Parasitology, Universidade Federal de Pelotas, UFPel, Pelotas, RS, Brazil. E-mail: nataliasmartins@outlook.com; sarapatron@hotmail.com; carol_csantos@hotmail.com; andriossilvamoreira@gmail.com

2 Undergraduate Student, School of Veterinary Medicine, UFPel, Pelotas, RS, Brazil. E-mail: evaristo.medvet@gmail.com

3 Prof. Dr., Department of Microbiology and Parasitology, UFPel, Pelotas, RS, Brazil. E-mail: naraameliafarias@gmail. com

${ }^{4}$ Veterinarian, Dr., Regional Diagnostic Laboratory, UFPel, Pelotas, RS, Brazil. E-mail: jeronimo.ruas@gmail.com

* Author for correspondence

Received: July 19, 2021 - Approved: Oct. 25, 2021 


\section{Resumo}

As infecções por Eimeria são comuns na ovinocultura em todo o mundo, porém informações sobre sua epidemiologia são escassas no sul do estado do Rio Grande do Sul, Brasil. Portanto, um estudo transversal foi realizado para determinar a prevalência, caracterização das espécies e fatores de risco associados entre espécies de Eimeria e rebanhos ovinos. Amostras fecais de 428 ovinos, de 21 fazendas, foram testadas para a presença de oocistos. A prevalência geral de Eimeria spp. foi $68,69 \%$, sendo significativamente afetada pela idade dos ovinos, com maior prevalência em animais menores de 18 meses. Oito espécies de Eimeria foram identificadas; Eimeria ovinoidalis (85,71\%) foi a mais comum, seguida por Eimeria crandallis (80,95\%), Eimeria granulosa (78,95\%), Eimeria ahsata (61,90\%), Eimeria faurei (42,86\%), Eimeria bakuensis (38,10\%), Eimeria punctata (14,29\%) e Eimeria pallida (9,52\%). Todos os rebanhos foram positivos, com infecções concomitantes. Entre as práticas de manejo e criação; tamanho da fazenda, densidade animal, sistema de criação, objetivo de criação e sistema de pastagem tiveram influência sobre a prevalência de Eimeria spp. A infecção foi mais prevalente em pequenas propriedades com alta densidade animal, em ovinos destinados a produção de carne, sistema semi-intensivo de criação e pastejo rotacionado $(p<0,05)$. A ampla distribuição desse protozoário e a alta frequência de espécies patogênicas mostram a importância e os danos potenciais da coccidiose ovina nos rebanhos gaúchos.

Palavras-chave: Coccidiose. Eimeria crandallis. Eimeria ovinoidalis. Ovinos.

\section{Introduction}

Coccidiosis is one of the most important parasitic diseases of small ruminants worldwide. It is caused by coccidian parasites of the genus Eimeria which develop in the small and large intestines. Coccidiosis has considerable economic importance, causing decreases in productivity, low growth performance, diarrhea, and mortality (Khodakaram-Tafti \& Hashemnia, 2017). Furthermore, treatment costs are high and are not always economically viable, especially in subclinical infections (Rodrigues et al., 2017). Many Eimeria infections in sheep are asymptomatic; however, more frequently in lambs, some species have been associated with diarrhea and stunted growth (Chartier \& Paraud, 2012). Infections occur due to the ingestion of sporulated oocysts and the hosts can be simultaneously infected by different species of the parasite. Currently, 11 Eimeria species are recognized as causing sheep infections, with $E$. ovinoidalis being the most pathogenic followed by $E$. crandallis and $E$. ahsata (Andrews, 2013; Bangoura \& Bardsley, 2020; Gregory Catchpole, Nolan, \& Hebert, 1989). Species differentiation remains a challenge, requiring coprological examination with a precise morphometric analysis of sporulated oocysts (Macedo et al., 2019).

Clinical signs are unapparent in most Eimeria infected animals. However, it is common to have some degree of inappetence or anorexia, weight loss, growth retardation, rough hair coat, and weakness (Andrews, 2013). Infection leads to underdevelopment due to parasite multiplication occurring within enterocytes, which causes villous atrophy, leading to malabsorption of nutrients. Fecal smearing may occur around the hindquarters due to diarrhea. As the clinical condition worsens, lambs develop profuse watery 
diarrhea that may contain blood-streaks (Keeton \& Navarre, 2017). If treatment is not undertaken, intense dehydration can lead to death. The severity of infection is a result of multiple conditions, including decreased host immunity, high parasite load, management and sanitary conditions, animal density, breed susceptibility, and presence of pathogenic Eimeria species (Khodakaram-Tafti \& Hashemnia, 2017; Rodrigues et al., 2017).

Coccidiosis is frequent and potentially damaging to sheep in southern Rio Grande do Sul, as previously reported (Martins et al., 2020). However, epidemiology data of this parasitosis in the state are scarce, especially on the risk factors associated with Eimeria. Thus, the aim of this study was to report epidemiological data of Eimeria spp. infections in sheep flocks in southern Rio Grande do Sul, Brazil, evaluating the prevalence and associated risk factors.

\section{Material and Methods}

\section{Study area and sample collection}

The current study was conducted on 21 farms from 11 cities of the southern Rio Grande do Sul state, Brazil, from August 2018 to September 2019 (Figure 1). The minimum sample size ( $n=384$ ) was estimated, with Epilnfo $^{T M}$ epidemiological calculators, based on the sheep population ( $n=499,898$ ) of the study area (Instituto Brasileiro de Geografia e Estatística [IBGE], 2017). A confidence level of $95 \%$, expected frequency of $50 \%$, and statistical error of $5 \%$ were considered. Animals enrolled in this study were observed for the presence of clinical signs related to coccidiosis (low body condition, diarrhea, apathy, and emaciation). In total, 428 fecal samples were obtained rectally and analyzed for the detection of Eimeria oocysts. On each farm, at least $10 \%$ of the total sheep population was included in the study. 


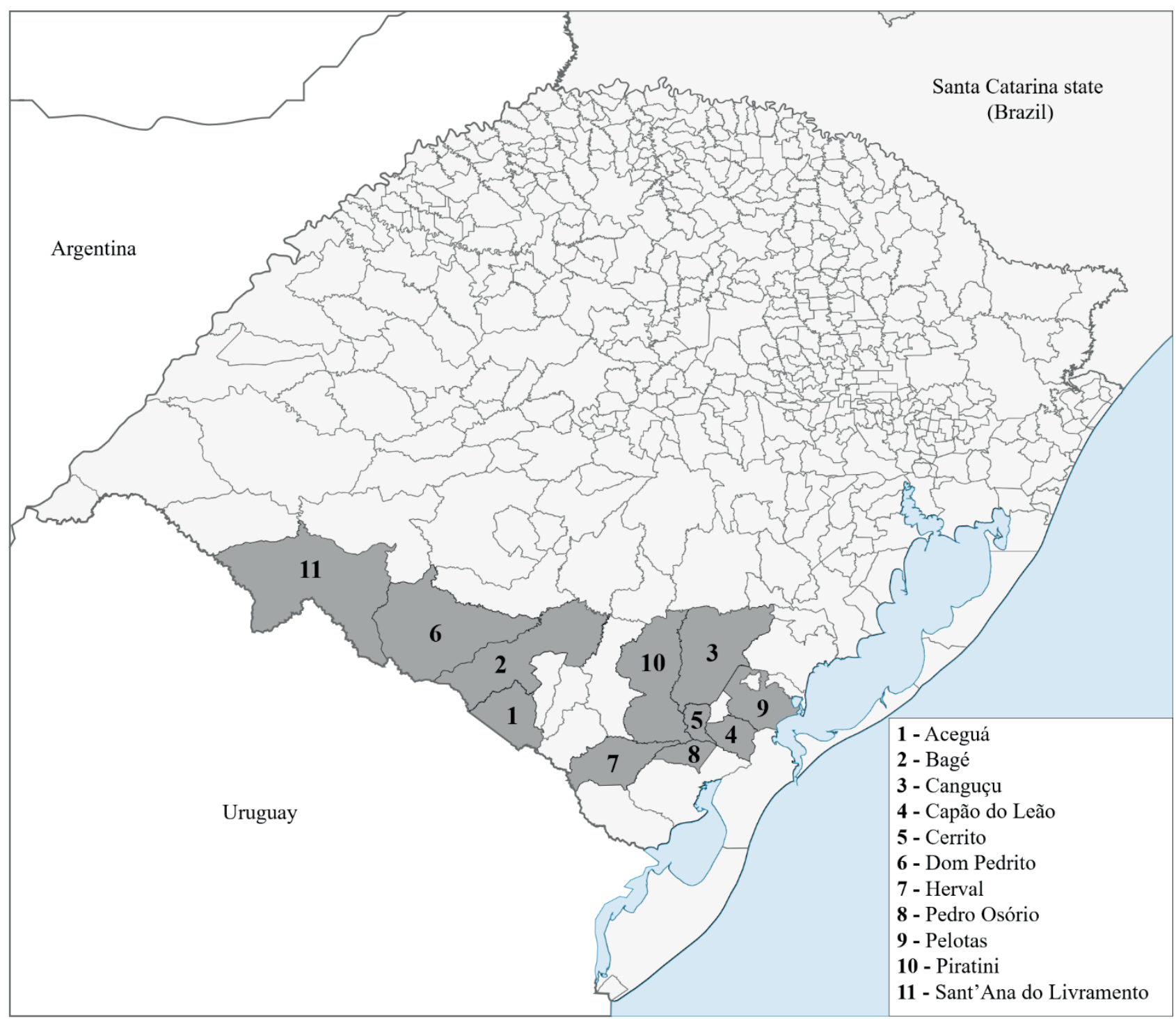

Figure 1. Cities from the southern Rio Grande do Sul state, Brazil, where sheep stool samples were collected for the detection of Eimeria in 2018 and 2019.

All procedures performed in this study were approved by the Ethics Commission on Animal Experimentation of the Federal University of Pelotas under protocol number $15450 / 2018$.
Coprological analysis

Samples were screened using the modified Gordon and Whitlock technique (Ueno \& Gonçalves, 1998), estimating the presence and number of oocysts per gram of feces (OPG). Subsequently, positive samples from each farm were pooled and stored in conical centrifuge tubes containing $2.5 \%$ 
potassium dichromate $\left(\mathrm{K}_{2} \mathrm{Cr}_{2} \mathrm{O}_{7}\right)$, which were moved regularly to allow oxygenation and kept at room temperature for ten days until sporulation of Eimeria oocysts was completed (Carrau et al., 2018). The Sporulated oocysts were separated from the fecal mixture and potassium dichromate using a modified centrifugal flotation technique (Duszynski \& Wiiber, 1997). Ultimately, 100 oocysts from each pooled sample were randomly selected on optical microscopy examination. In samples with less than 100 oocysts, all were analyzed. Species differentiation was based on morphometric and morphological characteristics, such as shape, color, and presence or absence of micropyle and micropylar caps, following Souza et al. (2015) and Macedo et al. (2019).

\section{Statistical analysis and risk factors}

Sheep within a farm were considered to form one group, as all animals were exposed to the same risk of extrinsic infection. Because animal management and farming systems were diverse between farms, the risks were considered different. Consequently, the experimental unit was the farm, not the individual sheep. Therefore, after coprological screening, the positive samples were pooled in order to obtain one sample per flock. A farm was classified as positive when Eimeria oocysts were detected in at least one of the sheep investigated on the farm.

A structured questionnaire was administered via a face-to-face interview with the farmers, to assess their knowledge of sheep health and husbandry and farm management practices, this information was used to search for risk factors associated with coccidiosis. Visual observations were also made to confirm questionnaire responses and assess farming practices. Information about the following variables was collected through a questionnaire:

1. Age: animals less than 18 months old were considered as young, the others as adults.

2. Breed: Corriedale, Ideal, Texel, and mixedbreed were studied.

3. Production system and management: type of farming system (intensive, extensive, or semi-intensive), breeding objectives (meat, wool, or multi-purpose), grazing management (continuous or rotational grazing and/or multi-species grazing), watering system (treated water or pond), acquisition and quarantine of new animals, herd size (animal density), and farm size (small, medium, or large). The farm size classification was defined by Brazilian law (Lei $\left.n^{\circ} 8.629,1993\right)$ and considers the fiscal module and not just the measure, which varies according to each city.

4. Herd health: sheep mortality and presence of diarrhea.

5. Veterinary assistance and knowledge about coccidiosis.

For the descriptive analysis, the Excel $^{\circledR} 2019$ software package was used. To identify the management characteristics associated with Eimeria species presence, a univariate analysis was performed using the chi-square $\left(x^{2}\right)$ or Fischer's exact test (when less than five observations were observed in the test quadrant). Variables that showed an association with $p \leq 0.2$ by the $x^{2}$ test or Fischer's exact test were selected for multiple model construction. Finally, Generalized Estimating Equations a multiple logistic regression model, was used to verify the association between the factors. 


\section{Results and Discussion}

Out of all samples analyzed, the prevalence of Eimeria was 68.69\% (294/428) with a mean of 3126.21 OPG. Young animals had a higher prevalence and released a greater number of oocysts when compared to adults $(p<0.05)$ (Table 1). No significant changes of color, odor, or consistency were identified in the fecal samples. Diarrhea was not observed in the analyzed sheep although, on some farms, poor body condition and apathy was noted.

Table 1

Mean of OPG ${ }^{1}$ and prevalence (\%) of Eimeria spp. in sheep from southern state of Rio Grande do Sul, Brazil

\begin{tabular}{|ccccc|}
\hline Animal category & Mean OPG & Prevalence & $p$ value & Odds ratio \\
\hline Young (<18 months) & 5492.40 & $86.55 \%$ & $<0.0001$ & 7.3 \\
\hline Adult & 194.20 & $46.60 \%$ & &
\end{tabular}

${ }^{1} \mathrm{OPG}=$ Oocysts per gram of feces.

Young sheep were more heavily parasitized by Eimeria, agreeing with previous reports (Carrau et al., 2018; Lopes et al., 2013; Khan et al., 2011; Souza et al., 2015). Eimeria is an intracellular parasite whose multiplication occurs within the cytoplasm of epithelial cells causing cell necrosis. As a result of diminished epithelial turnover in young animals, they are most susceptible to infection (KhodakaramTafti \& Hashemnia, 2017). In the first days of life, sheep start ingesting sporulated oocysts with food or water, presenting a progressive increase in the prevalence and intensity of oocyst excretion by lambs until a peak is reached around the weaning period. Thereafter, the excretion intensity decreases to reach lower values as the sheep grow (Chartier \& Paraud, 2012), which is compatible with the results of the OPG mean between young and adult sheep. Adult animals generally become immune to coccidiosis but serve as a reservoir for lambs. The severity of infection, clinical signs, and oocyst excretion are affected by the Eimeria species involved, level of environmental exposure, and animal immunity (Keeton \& Navarre, 2017).

Eimeria was detected in all herds studied (100\%). Eight Eimeria species were identified during coproparasitological examination. E. ovinoidalis $(85.71 \%)$ was the most common, followed by $E$. crandallis (80.95\%), Eimeria granulosa (78.95\%), Eimeria ahsata (61.90\%), Eimeria faurei (42.86\%), Eimeria bakuensis (38.10\%), Eimeria punctata (14.29\%), and Eimeria pallida (9.52\%). Mixed infection was found on all farms. Furthermore, analysis of all the risk factors on the farms revealed that farm size, breed size, breeding objectives, farming system, and pasture system were the factors significantly associated $(p<0.05)$ with Eimeria species infection (Table 2).

E. crandallis and E. ovinoidalis were the most prevalent in the present study. These two species are highly pathogenic for sheep 
and are usually associated with reduced fluid absorption and consequent diarrhea but are also known to induce strong protective immunity without clinical signs (Andrews, 2013; Carrau et al., 2018). The detected nonpathogenic species, E. ahsata, E. bakuensis, E. faurei, E. granulosa, E. pallida, E. parva, $E$. punctata, may be involved in cases of subclinical coccidiosis causing impairment of growth due to nutrient malabsorption (Keeton \& Navarre, 2017; Taylor, Coop, \& Wall, 2017). Concomitant infections were found on all analyzed farms. It is noteworthy that polyparasitism can aggravate the pathogenic effect of coccidia and may trigger more serious effects (Chartier \& Paraud, 2012). Previous studies conducted in Brazil have already described the presence of these species infecting sheep with variable prevalence (Lopes et al., 2013; Macedo et al., 2019; Martins et al., 2020; Souza et al., 2015).

As mentioned before, some factors can interfere with Eimeria prevalence and distribution, including management and sanitary conditions, host immunity, and breed susceptibility (Khodakaram-Tafti \& Hashemnia, 2017). With that understanding, risk factors that could be related to Eimeria occurrence in the studied region were estimated. The results indicated that some management conditions presented a relevant risk factor with a significant influence on sheep coccidiosis (Table 2).

Table 2

Risk factors associated with Eimeria species on sheep breeding farms from the southern Rio Grande do Sul state, Brazil

\begin{tabular}{|c|c|c|c|c|}
\hline \multicolumn{5}{|c|}{ Associated variables $^{1}$} \\
\hline Independent variables & Parasite specie & Frequency & $p$ value & Odds ratio \\
\hline \multicolumn{5}{|l|}{ Farm size } \\
\hline Small & Eimeria ahsata & $88.9 \%$ & 0.035 & 0.05 \\
\hline \multicolumn{5}{|l|}{ Herd size } \\
\hline \multirow{2}{*}{ High animal density } & Eimeria ahsata & $53.85 \%$ & 0.036 & 2.128 \\
\hline & Eimeria crandallis & $84.6 \%$ & 0.002 & 18.33 \\
\hline \multicolumn{5}{|l|}{ Breeding objectives } \\
\hline Meat & Eimeria crandallis & $93.8 \%$ & 0.028 & 22.500 \\
\hline \multicolumn{5}{|l|}{ Farming system } \\
\hline \multirow{2}{*}{ Semi-intensive } & Eimeria faurei & $37.5 \%$ & 0.042 & 0.1538 \\
\hline & Eimeria punctata & $80 \%$ & 0.048 & 0.100 \\
\hline \multicolumn{5}{|l|}{ Pasture system } \\
\hline Rotational grazing & Eimeria ovinoidalis & $88.9 \%$ & 0.035 & 0.050 \\
\hline
\end{tabular}

${ }^{1}$ Multiple logistic regression estimated by Generalized Estimating Equations; only factors that remained with a statistically significant association are included $(p<0.05)$. 
Poor sanitation was considered as a risk factor for coccidiosis. This condition allows higher food and water contamination by sporulated oocysts, increasing sheep exposure to infection. Furthermore, paddock and facility overcrowding interfere with animal welfare and can result in a high burden of Eimeria infection by stress-induced immunosuppression (Khodakaram-Tafti \& Hashemnia, 2017). On small properties with a high animal density, animals were bred for slaughter. Furthermore, on these farms there was a higher risk of infection by $E$. ahsata ( $p$ $=0.036$ ) and $E$. crandallis $(p=0.002)$. Similar results were obtained by Cai and Bai (2009) who observed greater oocyst excretion in high density herds. This fact may be related to stressful situations that sheep are exposed to, interfering with their immunological status and making them more susceptible to coccidiosis (Cai \& Bai, 2009).

The farming system has already been described as a possible risk factor for coccidiosis (Lopes et al., 2013; Macedo et al., 2019). In the semi-intensive system, sheep are confined at night. On some farms the animals receive food supplementation, and most animals were kept in small and poorly maintained barns. This practice is common in Rio Grande do Sul to avoid predation and sheep theft. In this breeding system, a higher frequency of nonpathogenic species E. faurei $(p=0.042)$ and E. punctata $(p=$ 0.048) was observed. Sheep housing and poor facility conditions may have influenced the occurrence of the species. The clinical importance of these data is unknown; however, it cannot be ignored.

Grazing management can be performed differently according to the production system. Native grasslands were considered as the main food source on the study farms, these grasslands present a great structural diversity in native forage species, with almost 800 grasses and 200 legumes (Nabinger, Moraes, \& Maraschin, 2000). This uncultivated land consists of natural plant species, usually extensively grazed. Compared with native grasslands, pasture is cultivated with intentional species planting, irrigation, and fertilizers, and are managed more intensively (Eagle \& Olander, 2012). Furthermore, rotational grazing is a system where a pasture is separated into smaller paddocks and the group of animals is moved regularly between paddocks, usually staying for 3-14 days; it is crucial that pastures are allowed to rest and recover to maintain adequate forage production (Eagle \& Olander, 2012). Rotational grazing was used for $33.4 \%$ of farms in order to provide forage at ideal stages of height, nutrient concentration, and digestibility. These farms had a higher frequency of parasitism by $E$. ovinoidalis, with a statistical difference in relation to continuous grazing ( $p=0.035$ $\mathrm{OR}=0.050)$. Rotational grazing contributes to parasite control in livestock (Burke \& Miller, 2020); however, it is ineffective when used alone or incorrectly, as it can provide an ideal environment for parasite proliferation, allowing autoinfection and timing the next grazing at the peak of parasite availability (Colvin, WalkdenBrown, Knox, \& Scott, 2008).

Clinical signs of Eimeria infection are usually minimal and unapparent; however, depression, weakness, abdominal pain, anorexia, with reduced weight gain, weight loss, dehydration and diarrhea may be observed, and in some cases, coccidiosis can lead to sudden death without previous digestive signs (Chartier \& Paraud, 2012; Keeton \& Navarre, 2017). The main symptom 
of coccidiosis is diarrhea and may precede oocyst shedding; however, oocyst excretion may also be high without any clinical signs (Chartier \& Paraud, 2012). In total, 38.09\% of farmers reported having observed animals with diarrhea, especially lambs, although no significant changes in stool characteristics were observed in the collected samples. Nevertheless, some animals presented at least one suggestive clinical sign of coccidiosis, such as poor body condition, softer fecal pellets, rough hair coat, and apathy. Similar observations were described in a preliminary study, where animals with high prevalence and Eimeria oocyst elimination had no distinction in stool consistency (Martins et al., 2020). In fact, the high prevalence and absence or non-specificity of clinical signs indicates the occurrence of subclinical coccidiosis in the study herds. This silent illness is hard to detect and expensive to treat. Rodrigues et al. (2017) showed that subclinical coccidiosis treatment is economically unfeasible; however, it may be viable when used to prevent weight loss from clinical coccidiosis.

The results presented in this study confirm the importance of coccidiosis in southern Rio Grande do Sul and emphasize the need to implement a diagnosis and control system. Even though there was veterinary assistance on $52.38 \%$ of the farms, only four only four of the 21 people interviewed claimed to know about coccidiosis. This indicates a lack of knowledge about the disease and its impacts on herd health. Promoting strategies, through education and training programs for infection prevention, with farmers and veterinarians, must be the priority for improving the entire coccidiosis prevention and control system.

\section{Conclusion}

Overall prevalence results confirmed a high prevalence and wide distribution of Eimeria infections in sheep from southern Rio Grande do Sul, Brazil. The infection is endemic, particularly in young animals. Eimeria was detected in all herds studied, with mixed infections. Eight Eimeria species have been identified and it has been shown that the highly pathogenic E. ovinoidalis and $E$. crandallis dominate. The risk of infection increases on small farms with high animal density, poor grazing management and poor sanitary conditions. These findings highlight the importance of ovine coccidiosis and serve as an alert for veterinarians regarding the presence of pathogenic species in sheep. Appropriate sanitary measures must be encouraged to prevent infection and consequent economic loss.

\section{Acknowledgments}

This study was financed in part by the Coordenação de Aperfeiçoamento de Pessoal de Nível Superior - Brasil (CAPES) - Finance Code 001. The authors would also like to express their gratitude and appreciation to the farmers and veterinarians who participated in this research.

\section{References}

Andrews, A. H. (2013). Some aspects of coccidiosis in sheep and goats. Small Ruminant Research, 110(2-3), 93-95. doi: 10.1016/j.smallrumres.2012.11.011

Bangoura, B., \& Bardsley, K. D. (2020) Ruminant coccidiosis. Veterinary Clinics of North 
America: Food Animal Practice, 36(1), 187-203. doi: 10.1016/j.cvfa.2019.12.006

Burke, J. M., \& Miller, J. E. (2020). Sustainable approaches to parasite control in ruminant livestock. Veterinary Clinics of North America: Food Animal Practice, 36(1), 89107. doi: 10.1016/j.cvfa.2019.11.007

Cai, K. Z., \& Bai, J. L. (2009). Infection intensity of gastrointestinal nematodosis and coccidiosis of sheep raised under three types of feeding and management regims in Ningxia Hui Autonomous Region, China. Small Ruminant Research, 85(2-3), 111-115. doi: 10.1016/j.small rumres.2009.07.013

Carrau, T., Silva, L. M. R., Pérez, D., Failingd, K., Martínez-Carrasco, C., Macías, J.,... Ruiz de Ybáñez, R. (2018). Associated risk factors influencing ovine Eimeria infections in southern Spain. Veterinary Parasitology, 263, 54-58. doi: 10.1016/j. vetpar.2018.10.004

Chartier, C., \& Paraud, C. (2012). Coccidiosis due to Eimeria in sheep and goats, a review. Small Ruminant Research, 103(1), 84-92. doi: 10.1016/j.smallrumres.2011.10.022

Colvin, A. F., Walkden-Brown, S. W., Knox, M. R., \& Scott, J. M. (2008). Intensive rotational grazing assists control of gastrointestinal nematodosis of sheep in a cool temperate environment with summer-dominant rainfall. Veterinary Parasitology, 153, 108120. doi: 10.1016/j.vetpar.2008.01.014

Duszynski, D. W., \& Wiiber, P. G. (1997). A guideline for the preparation of species descriptions in the Eimeriidae. The Journal of Parasitology, 83(2), 333-336.

Eagle, A. J., \& Olander, L. P. (2012). Greenhouse gas mitigation with agricultural land management activities in the United States-a side-by-side comparison of biophysical potential. In D. L. Sparks (Ed.),
Advances in agronomy. Cambridge, MA: Academic Press.

Gregory, M. W., Catchpole, J., Nolan, A., \& Hebert, C. N. (1989). Ovine coccidiosis: studies on the pathogenicity of Eimeria ovinoidalis and $E$. crandallis in conventionally-reared lambs, including possible effects of passive immunity. Deutsche Tierarztliche Wochenschrift, 96(6), 287-292.

Instituto Brasileiro de Geografia e Estatística (2017). Censo agropecuário 2017. Recuperado de https://censoagro2017. ibge.gov.br/templates/censo_agro/ resultadosagro/pecuaria.html? localidade $=43 \&$ tema $=75674$

Keeton, S. T. N., \& Navarre, C. B. (2017). Coccidiosis in large and small ruminants. Veterinary Clinics of North America: Food Animal Practice, 34(1), 201-208. doi: 10.1016/j.cvfa.2017.10.009

Khan, M. N., Rehman, T., Iqbal, Z., Sajid, M. S., Ahmad, M., \& Riaz, M. (2011). Prevalence and associated risk factors of Eimeria in sheep of Punjab, Pakistan. International Scholarly and Scientific Research \& Innovation, 5(7), 1329-1334.

Khodakaram-Tafti, A., \& Hashemnia, M. (2017). An overview of intestinal coccidiosis in sheep and goats. Revue de Médecine Vétérinaire, 167(1-3), 9-20.

Lein ${ }^{\circ} 8.629$, de 25 de fevereiro de 1993. Dispõe sobre a regulamentação dos dispositivos constitucionais relativos à reforma agrária, previstos no Capítulo III, Título VII, da Constituição Federal. Recuperado de http://www.planalto.gov.br/ccivil_03/leis/ 18629.htm

Lopes, W. D. Z., Borges, F. A., Faiolla, T. P., Antunes, L. T., Borges, D. G. L., Rodriguez, F. S.,... Martinez, A. C. (2013). Eimeria species in young and adult sheep raised under intensive and/or semi-intensive 
systems of a herd from Umuarama city, Parana State, Brazil. Ciência Rural, 43(11), 2031-2036. doi: 10. 1590/S010384782013001100018

Macedo, L. O., Santos, M. A. B., Silva, N. M. M., Barros, G. M. M. R., Alves, L. C., Giannelli, A.,... Carvalho, G. A. (2019). Morphological and epidemiological data on Eimeria species infecting small ruminants in Brazil. Small Ruminant Research, 171, 37-41. doi: 10.1016/j.smallrumres.2018.12.006

Martins, N. S., Motta, S. P., Santos, C. C., Moreira, A. S., Farias, N. A. R., \& Ruas, J. R. (2020). Eimeria spp. infection in lambs from southern Brazil. Brazilian Journal of Veterinary Research, 40(11), 871-874. doi: 10.1590/1678-5150-PVB-6745

Nabinger, C., Moraes, A., \& Maraschin, G. E. (2000). Campos in Southern Brazil. In G. Lemaire, J. Hodgson, A. de Moraes, C. Nabinger, \& P. C. de F. Carvalho (Eds.), Grassland ecophysiology and grazing ecology (pp. 355-376). New York, NY: CAB International.
Rodrigues, F. S., Cezar, A. S., Menezes, F. R. de, Sangioni, L. A., Vogel, F. S. F., \& Botton, S. A. (2017). Efficacy and economic analysis of two treatment regimens using toltrazuril in lambs naturally infected with Eimeria spp. on pasture. Parasitology Research, 116(11), 2911-2919. doi: 10.1007/s004 36-017-55 97-5

Souza, L. E. B., Cruz, J. F., Teixeira, M. R., Neto, Albuquerque, G. R., Melo, A. D. B., \& Tapia, D. M. T. (2015). Epidemiology of Eimeria infections in sheep raised extensively in a semiarid region of Brazil. Brazilian Journal of Veterinary Parasitology, 24(4), 410-415. doi: 10.1590/S1984-29612015070

Taylor, M. A., Coop, R. L., \& Wall, R. L. (2017). Parasitas de ovinos e caprinos. In $\mathrm{M}$. A. Taylor, R. L. Coop, \& R. L. Wall (Eds.), Parasitologia veterinária (pp. 1733-1758). Rio de Janeiro, RJ: Guanabara Koogan.

Ueno, H., \& Gonçalves, P. C. (1998). Manual para o diagnóstico das helmintoses de ruminantes. Tokyo: International Cooperation Agency. 
